[Agr. Biol. Chem., Vol. 31, No. 1, p. 115 118, 1967]

\title{
Study on Soybean Lipoxygenase
}

\section{Part I. Preparation of Crystalline Enzyme and Assay by Polarographic Method}

\author{
By Hisateru Mitsuda, Kyoden Yasumoto, Aijiro Yamamoto \\ and Takanori Kusano \\ Department of Agricultural Chemistry, Faculty of Agriculture, Kyoto University, Kyoto
}

Received July 5, 1966

Lipoxygenase (E.C. 1.99.2.1) specifically catalyzes the oxidation of methylene-interrupted unsaturated fatty acids and their esters to respective hydroperoxides. The most typical substrate is naturally occurring isomers of linoleic, linolenic, and arachidonic acids. ${ }^{1 !}$ Although the physiological significance of lipoxygenase in plants remains to be clarified, development of undesirable flavor in unblanched vegetables during storage has been found related with the lipoxygenase reaction. ${ }^{2}$ On the other hand, crude enzyme preparation has been used in actual bread making in order to improve the rheological properties of dough ${ }^{31}$ and to enhance flavor development in baked materials." A certain concern has been paid to the limited knowledges on catalytic properties and protein natures of this enzyme, while its function has increasingly become evident in food technological and nutritional fields. ${ }^{5}$ However, difficulties encountered in obtaining pure enzyme preparation and in

1) R. T. Holman and S. Bergström, "The Enzyme" ed. by J. B. Sumner and K. Myrbäck, Vol. 2, Part 1, p. 536. Academic Press, New York, 1951.

2) A. C. Wagenknecht, Food Research, 17, 343 (1952).

3) R. B. Koch, Bakers Digest, 30 (2), 48 (1956).

4) A. W. Kleinschmidt, K. Higashiuchi, R. Anderson and C. G. Ferrari, Bakers Digest, 37 (5), 44 (1963)

5) H. Fukuba, Yukagaku, 14, 679 (1965). determining its activity quantitatively, especially in crude preparation, impede further understanding of this enzyme.

We present here that the crystalline enzyme can be reproducibly prepared and that the enzyme activity can be determined rather easily and satisfactorily by polarographic method than others available for this purpose.

Enzyme Preparation. The preparation of crystalline lipoxygenase from defatted soybean meal was a modification of the method of Theorell et al. ${ }^{6)}$ as follows. Defatted, lowtemperature-extracted soybean meal, in amount of $12 \mathrm{~kg}$, was suspended in 80 liters of $0.1 \mathrm{M}$ acetate buffer at $\mathrm{pH} 4.5$ and passed through a basket centrifuge. To the resulted extracts was added 0.1 volume of $1 \%$ sodium alginate solution at $\mathrm{pH} 4.2$. The active precipitate collected by decantation and filtration was homogenized with 6 liters of $0.2 \mathrm{M}$ sodium acetate, to which were added 0.05 volume of $20 \%$ barium acetate, 0.10 of acetone, and 0.02 of $20 \%$ basic lead acetate. The supernatant obtained after filtering off the insoluble materials was fractionated with ammonium sulfate between 40 and $60 \%$ saturation. Active precipitate was dissolved in a volume of water, approximately equal to the wet volume of the

6) H. Theorell, R. T. Holman and A. Akeson, Acta Chem. Scand., 1, 571 (1947). 


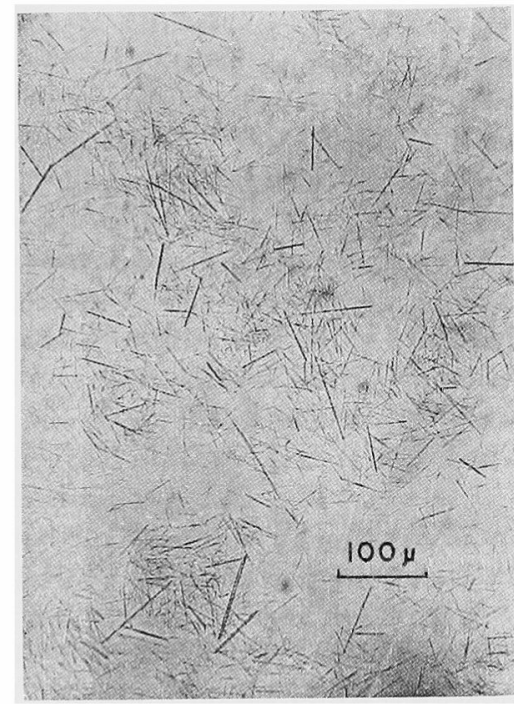

FIG. 1. Soybean Lipoxygenase Grystals from Ammonium Sulfate.

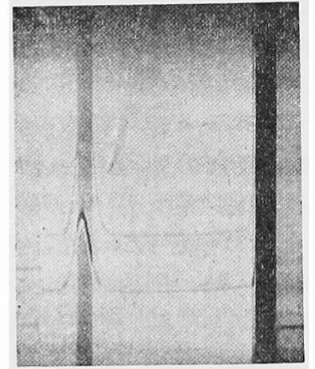

FIG. 2. Sedimentation Pattern of Soybean Lipoxygenase. The photograph was taken after 48 minutes of centrifugation with Spinco ultracentrifuge Model E driven at 59,780 r.p.m. at $4^{\circ} \mathrm{C}$. Upper pattern was for $1.0 \%$ and lower one for $0.5 \%$ protein solution in $0.02 \mathrm{M}$ phosphate buffer of $\mathrm{pH}$ 7.2. The mean value for $\mathrm{S}_{20, w}$ calculated with partial specific volume of 0.750 was $5.65 \mathrm{~S}$.

precipitate and centrifuged. The resultant supernatant was submitted to heat treatment at $63^{\circ} \mathrm{C}$ for 5 minutes, dialysis against $0.02 \mathrm{M}$ phosphate buffer of $\mathrm{pH} 5.5$, and subsequent fractionation between 10 and 20\% concentration of ethanol. Precipitate was dissolved in and dialyzed against $0.125 \mathrm{M}$ acetate buffer of $\mathrm{pH}$ 5.5. The clear solution obtained after centrifugation was poured into a CM-
Sephadex C-50 column which was previously equilibrated with the same buffer. The column was washed with about 7 to 8 hold-up volumes of that buffer and then with $0.175 \mathrm{~m}$ acetate buffer of $\mathrm{pH}$ 5.5. Active fraction issued from the column after about 3 hold-up volumes of $0.175 \mathrm{~m}$ buffer was collected and precipitated by adding saturated ammonium sulfate solution to $60 \%$ saturation. Precipitate collected was dissolved in and dialyzed against $0.07 \mathrm{M}$ veronal buffer of $\mathrm{pH}$ 8.6. Glear colorless supernatant obtained after centrifugation was slowly dialyzed against ammonium sulfate solution of 45 to $50 \%$ saturation.

Rod-shaped crystals as shown in Fig. 1 were obtained, while Theorell et al. obtained plates or sheaves. ${ }^{6}$ ) It was found homogeneous electrophoretically on cellulose acetate membrane and ultracentrifugally as shown in Fig. 2. Molecular weight obtained by thin-layer gel filtration on Sephadex G-100 plates ${ }^{7,81}$ was $102,000 \pm 3,000$, which is close to that reported by previous investigators. ${ }^{61}$ Specific activity determined by polarographic and spectrophotometric methods is presented in the Table I.

TABLE I. SPECIFIC ACtivity OBtAINed EXPERIMENTALLY AND THEORETICALLY AT $20^{\circ}$

Assay conditions were same as in two minutes method.16)
Assay method

Oxygen uptake:

Experimental

Theoreticala)

Absorbancy at $234 \mathrm{~m} \mu$ :

Experimentalb)

Reported $\mathbf{c}$ )
Specific activity

$\mathrm{O}_{2} \mathrm{M} \cdot \min ^{-1} \cdot \mathrm{A}_{280}{ }^{-1}$

$3.2 \times 10^{-2}$

$3.5 \times 10^{-2}$

Theorell Unit $\cdot \mathrm{A}_{260}{ }^{-1}$

$5.0 \times 10^{2}$

$4.8 \times 10^{2}$ a) Calculated from spectrophotometric assay data presented by Theorell et al.6), assuming that the molar extinction coefficient of linoleic hydroperoxide at $234 \mathrm{~m} \mu$ is $2.74 \times 10^{4} \mathrm{~cm}^{-1} \cdot \mathrm{M}^{-1}$.

b) Obtained by two minutes method, while a little higher value was resulted by reaction velocity method.

c) Taken from the literature.6:

7) H. Determann, Experientia, 18, 430 (1962).

8) E. Eieschlag and K. Otto, Z. Physiol. Chem., 340, 46 (1965). 
Experimentally determined oxygen uptake rate for the present preparation was quite close to the theoretically calculated value. Spectrophotometric assay always resulted in a little higher value than reported one.

Polarographic Determination of Lipoxygenase Activity. To measure the activity of lipoxygenase, a Clark oxygen electrode was used as a detector for the oxygen concentration in the reaction medium. Potential applied between platinum and silver electrodes via a polarograph circuit was 0.60 volt. The electrode assembly was fitted to a reaction vessel which was maintained at $25^{\circ} \mathrm{C}$ by circulating the temperature-controlled water in its jacket. The enzymic reaction was started by adding 0.05 to $0.10 \mathrm{ml}$ of properly diluted enzyme solution to 2.95 to $2.90 \mathrm{ml}$ of substrate solution which was prepared according to the direction of Tappel et al. ${ }^{91}$ from linoleic acid purchased from Fluka AG, Bucks SG, Switzerland ( $\geq 98 \%$ pure), and allowed equilibrated with atmosphere at $25^{\circ} \mathrm{C}$ in the reaction vessel.

Fig. 3 is examples of actual polarograph records. As will be seen, oxygen concentration in the reaction medium decreased with the time elapsed after addition of the enzyme. The initial rate of oxygen uptake was proportional to the amount of the enzyme added within the range of experimental error, provided the rate was lower than about $200 \mu \mathrm{M}$ oxygen per minute as shown in Fig. 4. The rate of oxygen uptake depended on the substrate concentration in a fashion similar to that reported by Tappel et al. ${ }^{101}$

Various techniques have been devised for the determination of lipoxygenase activity and much reliable results have been offered by these methods. Nevertheless, they involve following disadvantages, respectively. ${ }^{11 \prime}$

9) A. L. Tappel, P. D. Boyer and W. O. Lundberg, Arch. Biochem. Biophys., 42, 293 (1953).

10) A. L. Tappel, P.D. Boyer and W.O. Lundberg, J. Biol. Chem., 199, 267 (1953).

11) R. T. Holman, "Method of Biochemical Ana lysis" ed. by D. Glick, Vol. 2, p. 113. Interscience Pub., New York, 1955.

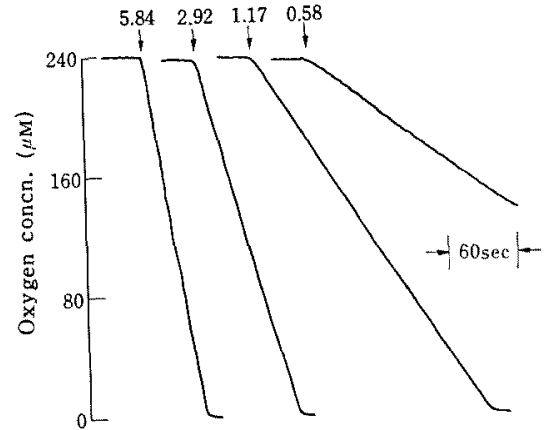

FIG. 3. Polarographic Records of Lipoxygenase Reaction. The reaction was started by adding $0.1 \mathrm{ml}$ of enzyme solution, containing indicated amount of protein in $\mu \mathrm{g}$, to $2.90 \mathrm{ml}$ of $7 \times 10^{-3} \mathrm{M}$ ammonium linoleate in $0.1 \mathrm{M}$ ammonium chloride buffer of $\mathrm{pH} 9.0$ after equilibration with atmosphere at $25^{\circ} \mathrm{C}$ to allow oxygen dissolve by $240 \mu \mathrm{M}$.

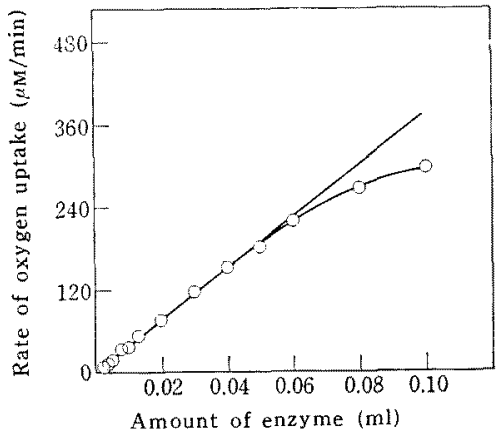

FIG. 4. Relationship between the Amount of Enzyme and the Initial Rate of Oxygen Uptake in Polarographic Assay. Crystalline enzyme diluted to contain $58.4 \mu \mathrm{g}$ per $\mathrm{ml}$ was added to the substrate solution as described in Fig. 3.

Colorimetric determination of destruction of carotenoids and related compounds, ${ }^{12,13 !}$ based upon the coupled oxidation by lipoxygenase, is a secondary reaction in the enzyme-catalyzed reaction, and thus the results obtained are an empirical nature; linear relationship between the enzyme concentration and the

12) A. K. Balls, B. Axelrod and M. W. Kies, J. Biol. Chem., 149, 491 (1943).

13) E. L. Cosby and J. B. Sumner, Arch. Biochem., 8, $259(1945)$. 
amount of carotenoids destructed exists over only a narrow range. Chromophore in ferric thiocyanate method, ${ }^{12,14}$ which determines the peroxide formed, is unstable. Manometric method, in which conventional Warburg apparatus is generally used, suffers from the fact that the rate of oxygen uptake is not proportional to the amount of enzyme used. ${ }^{151}$ Spectrophotometric methods are thought to be reliable to the utmost. However, two minutes method $^{16)}$ gives somewhat lower value as an induction period exists before the reaction proceeds at the maximum rate. ${ }^{171}$ Another spectrophotometric method developed by

14) R. B. Koch, B. Stern and C. G. Ferrari, Arch. Biochem. Biophys., 78, 165 (1958).

15) H. Theorell, S. Bergstrom and A. Akeson, Arkiv Kemi Mineral. Geol., A19 (6), (1944).

16) H. Theorell, S. Bergström and A. Akeson, Pharm. Acta Helv., 21, 318 (1946).

17) J.L. Haining and B. Axelrod, J. Biol. Chem., 232, 193 (1958).
Tappel et al., ${ }^{g, 10)}$ reaction velocity method, suffers from the difficulty in obtaining an optically clear and homogeneous substrate solution. In presence of substances which interfere the ultraviolet absorption at $234 \mathrm{~m} \mu$, it is hard to carry out the spectrophotometric methods.

Present method involves several advantages over other ones. The features to be pointed out among them are proportionality of the rate of oxygen uptake to the enzyme concentration, continual and direct measure of one of the reactants involved, that no restriction is imposed by the foreign substances contaminated or added, and variation of assay conditions in wide range with relative impunity for the impurities reactions. Characteristics of the crystalline preparation as a protein and as an enzyme revealed by using present method will be published elsewhere. 